\title{
The Impact of Water Oscillation on Hydrophytes and Macro algae Growth in Tigris River within Mosul Area
}

\author{
Mazin N. Fadhel \\ Department of Environmental Science \\ College of Environmental Science and Technology \\ University of Mosul \\ E-mail: fadhelm77@uomosul.edu.iq
}

(Received 14/ 5 / 2012 ; Accepted 10/9/2012)

\begin{abstract}
Two stations have been selected during the course of Tigris River within Mosul city; the first one is before entering the city, while the other located downstream the city. Results clearly exhibit a significant difference in water quality between the two locations.

Aquatic plants and macro-algae populations along about $17 \mathrm{Km}$ of the rivers course were identified. Six aquatic plant species have been identified Potamogeton pusillus, Potamogeton nodosus, Ceratophyllum demersus, Phragmites australis, Phragmites sp. and Typha sp.

Potamogeton pusillus a species was the predominant species during the study period, on the other hand macro-algae included Hydrodiction riticulatum, Cladophora glomerata, Chara vulgaris, Chara sp. and Nitella sp., the species Chara vulgaris and Cladophora glomerata from green algae phylum were the predominant species of the five algal identified species during the study period.

Clear trespass on the river banks was recorded, sand and gravel queries negatively affecting the river by forming shallow ponds and swamps which are perfect for aquatic plants and algae communities to prosper and flourish leads to dramatic detrimental impact on river health.
\end{abstract}

Keywords: Water deficiency, Hydrophytes and Macro-algae, Nutrients, Tigris River.

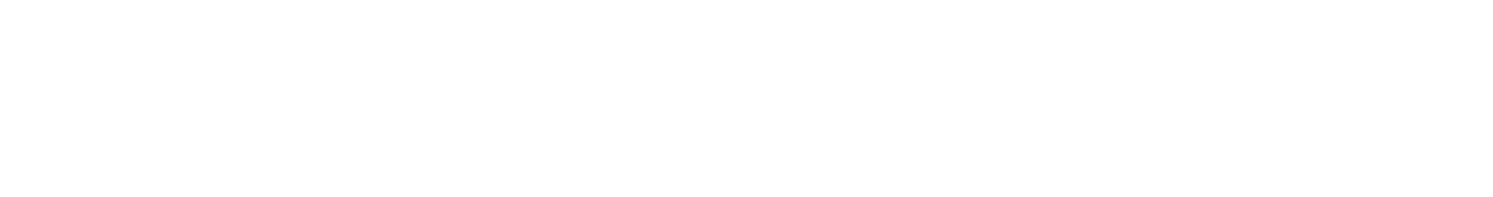

\section{المانص}

قم لختيار موقعن للدرلسة خلال مسار النهر ضمن مدينة الموصل، الموقع الأول قبل نخوله المدينة،

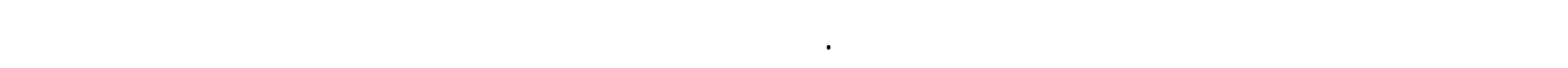
بحوالي 17 كم من مسار النهر، مُ التعرف على فيستة أنواع من النباتلت المائية وهي: Potamogeton pusillus, Potamogeton nodosus, Ceratophyllum demersus, Phragmites australis Phragmites sp. and Typha sp. 
لظٔهر النوع :Potamogeton pusillus سيادة على بقية الأنواع، من نلحية لخرى شملت الطحالب Hydrodiction riticulatum, Cladophora glomerata, Chara vulgaris, Chara sp. and Nitella sp. وكلن النوعلن Cladophora glomerata, Chara vulgaris العائدان الفم الطحالب الخضر هما النوعان اللسائدان من الأنواع الطحلبية الخمسة الني قم تشخيصها خلل مدة الدرلسة.

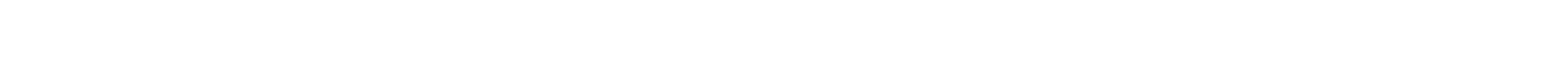

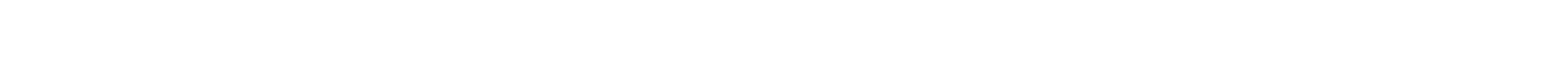
إلى أثار صارن برك وخطيرة على صحة النهر.

الكامل الدالة : قص الميه، النباتت المائية والطحالب الكبيرة، المغنيت، نهر نجلة.

\section{INTRODUCTION}

One of the main reasons that caused the deterioration of water quality and increased water deterioration is the problem of wastewater estuaries directed to the river. There is about three wastewater estuaries from Turkey to the Mosul lake and (15) estuary as wastewater passing through Mosul city, besides, wastewater that reaches the river from other industrial and agricultural activities (Ghazal, 1996). This problem exacerbated with the decrease of river flow level, where the river is in a continuous decrease of quantity, and the populations with different activities are in continuous growth. Consequently, the increase of what reaches the river of different wastes which were earlier vanished after the process of auto purification, diffusion and mixing up. The water flow speed and its high quantity help in this regard, for now this operation does not occur because of river flow decrease and the shortage of water level that the river became diseased and unable to manage the mixing up and self-purification of what reaches it of pollutants. There is also a lack in dissolved oxygen quantity accompanied with an increase of the required biological and chemical demand for oxygen (Kadah, 2001; APHA, 2005).

Primary nutrients of plants reach the river as a result of population activities which cause the huge growth of seed and seedless aquatic plants, besides many different kinds of algae and phytoplankton (Mustafa and Fadhel, 2008).

Locally, water is considered as a source of various fortunes and the main reason of peoples' life, it is worth mentioning that Tigris river is rich with fish supplies which is considered as the livelihood of many people, in addition of being the only drinking water source for citizens. The river is also considered as an important place for rest and relaxation, also, the river is considered as the only source of electricity by operating the electric generating stations by the force of water, in addition to the use of water in agricultural and industrial fields.

The main aim of this research is to explain the reasons of hydrophytes and macro algal growth and the impact of these plants on water quality. 


\section{STUDY AREA}

Two stations were selected along Tigris river within Mosul city for water analysis. Station 1 was selected before the river enters Mosul city upstream the river (Al-Rashediah) and the 2nd station after leaving the city downstream the river (Yaremjah) (Fig. 1). Hydrophytes and Macro algae were collected along the study area between station 1 and station 2 of a distance reach about 17 kilometers along Tigris river within Mosul city.

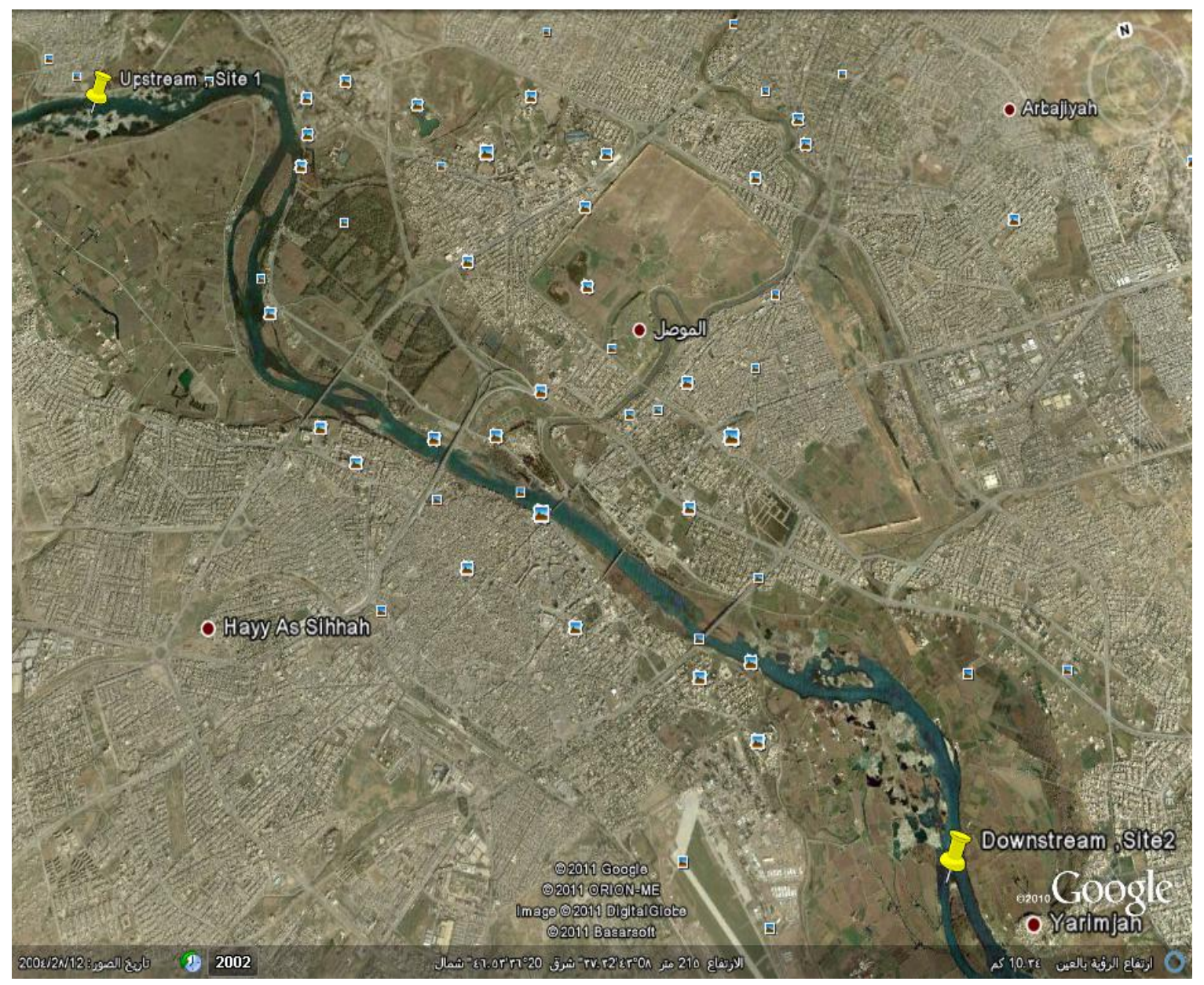

Fig. 1: Sites of Study area, Upstream and Downstream Mosul City.

\section{MATERIALS AND METHODS}

1- Monthly samples were collected from April to September 2010 for physical, chemical and biological analysis, water temperature, $\mathrm{pH}$ value, dissolved oxygen, biological oxygen demand, nutrients as nitrates and phosphates and turbidity were determined according to (APHA, 2005).

2- $\quad$ Aquatic plants and macro-algae were collected along the study area from both banks of the river and classified according to the following references (Muencher, 1959; Fassett, 1975; Prescott, 1978; Townsend and Guest, 1985; Al-Mayah and Al-Hamim, 1991). 


\section{RESULTS}

A significant variation was found between the stations of the study area, Table (1) shows water characteristics for the factors that have been measured.

In general, there was an increase in the concentration of most of the measured factors within the permissible limits for the use of river as a source of raw water (WHO, 1998). Also, it shows a comparison between two sites the first is before the river enters the City of Mosul, and the second is after its leave, this gives an indication of water quality in Mosul city and clarifies the changes happen on water quality during the river course inside the city.

Figures 1 to7 show the variance between measured parameters. Water temperature was changing according to the time of sample collection, $\mathrm{pH}$ values were closing to acidity in station 2 which reached to 6.4, the river turbidity increased in station 2 to reach $4.8 \mathrm{NTU}$, dissolved oxygen means were ranged between 7.2-5.8 mg/l, biological oxygen demand means ranged between 2.1-4.0 mg/l, the decreasing of dissolved oxygen and increasing of its demand was in station 2 after river leaving the city. Nitrate concentration means ranged between $0.03-1.1 \mathrm{mg} / \mathrm{l}$, phosphate concentrations were between $0.09-2.6 \mathrm{mg} / \mathrm{l}$, the highest concentration of measured parameters was in station 2 during the study period except the temperature which is changed with variation of seasons.

Table 1: Results of measured parameters.

\begin{tabular}{|l|c|c|c|c|c|c|}
\hline \multirow{2}{*}{ Parameter } & \multicolumn{2}{|c|}{$\begin{array}{c}\text { Spring } \\
\text { (April, May) }\end{array}$} & \multicolumn{2}{c|}{$\begin{array}{c}\text { Summer } \\
\text { (June, July, } \\
\text { August) }\end{array}$} & \multicolumn{2}{c|}{$\begin{array}{c}\text { Autumn } \\
\text { (Sept.) }\end{array}$} \\
\cline { 2 - 7 } & Site 1 & Site 2 & Site 1 & Site 2 & Site 1 & Site 2 \\
\hline Temp. C & 9.0 & 9.5 & 14.5 & 15.5 & 12.1 & 12.8 \\
\hline pH & 7.8 & 7.5 & 8.1 & 7.7 & 7.5 & 7.0 \\
\hline Turbidity, NTU & 3.0 & 3.8 & 2.8 & 4.0 & 3.0 & 4.8 \\
\hline DO mg/L & 7.8 & 6.0 & 6.4 & 5.0 & 7.2 & 5.8 \\
\hline BOD mg/L & 2.0 & 3.0 & 2.2 & 4.5 & 2.1 & 4.0 \\
\hline $\mathbf{N O}_{\mathbf{3}} \mathbf{~ m g / L ~}$ & 0.04 & 0.86 & 0.52 & 1.95 & 0.13 & 1.10 \\
\hline PO $_{\mathbf{4}} \mathbf{~ m g / L ~}$ & 0.10 & 1.9 & 1.53 & 4.1 & 0.09 & 2.6 \\
\hline $\mathrm{Al}^{2}$
\end{tabular}

All numbers represent the means of specific season, duplicates has been made for every measurement 


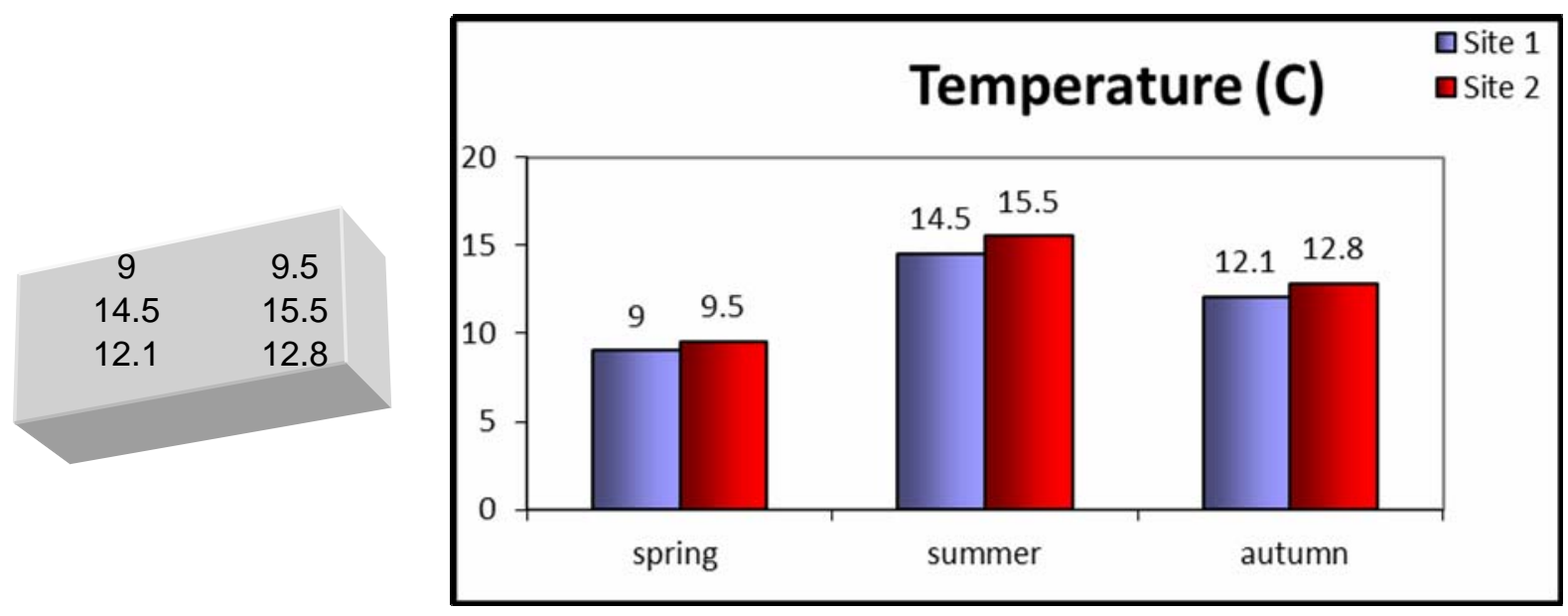

Fig. 1: Diagram of temperature values during study period

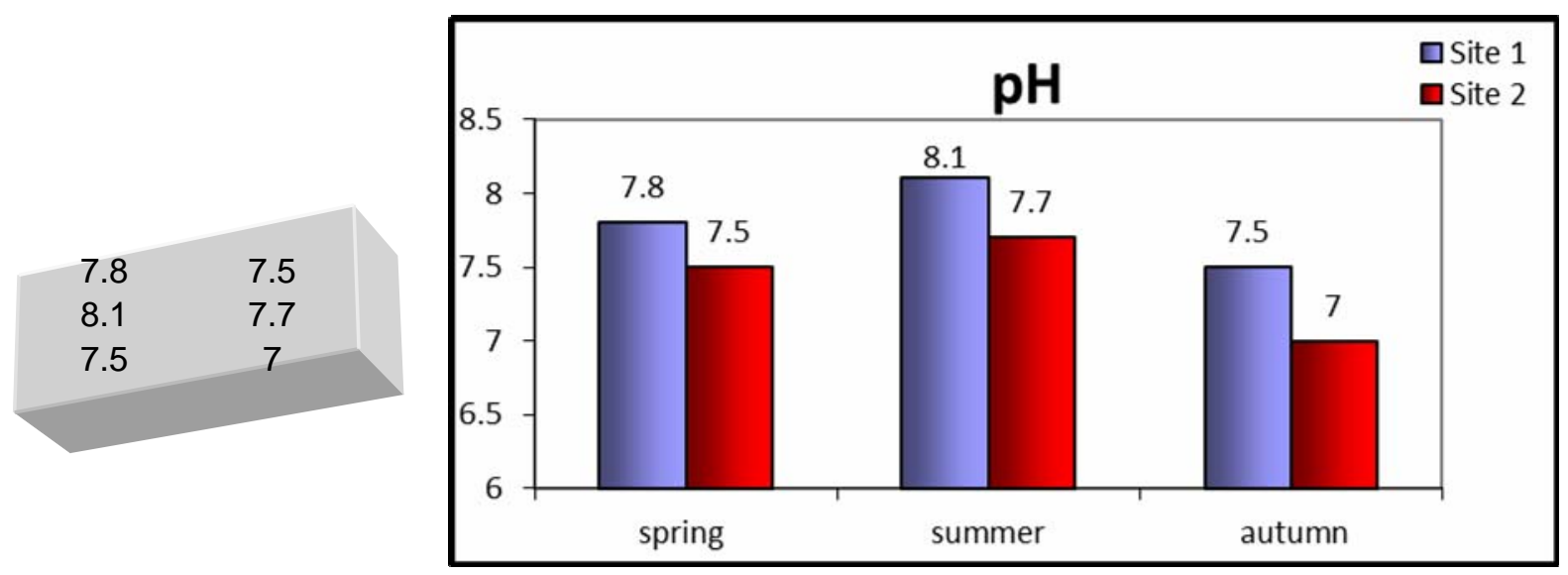

Fig. 2: Diagram of $\mathrm{pH}$ values during study period

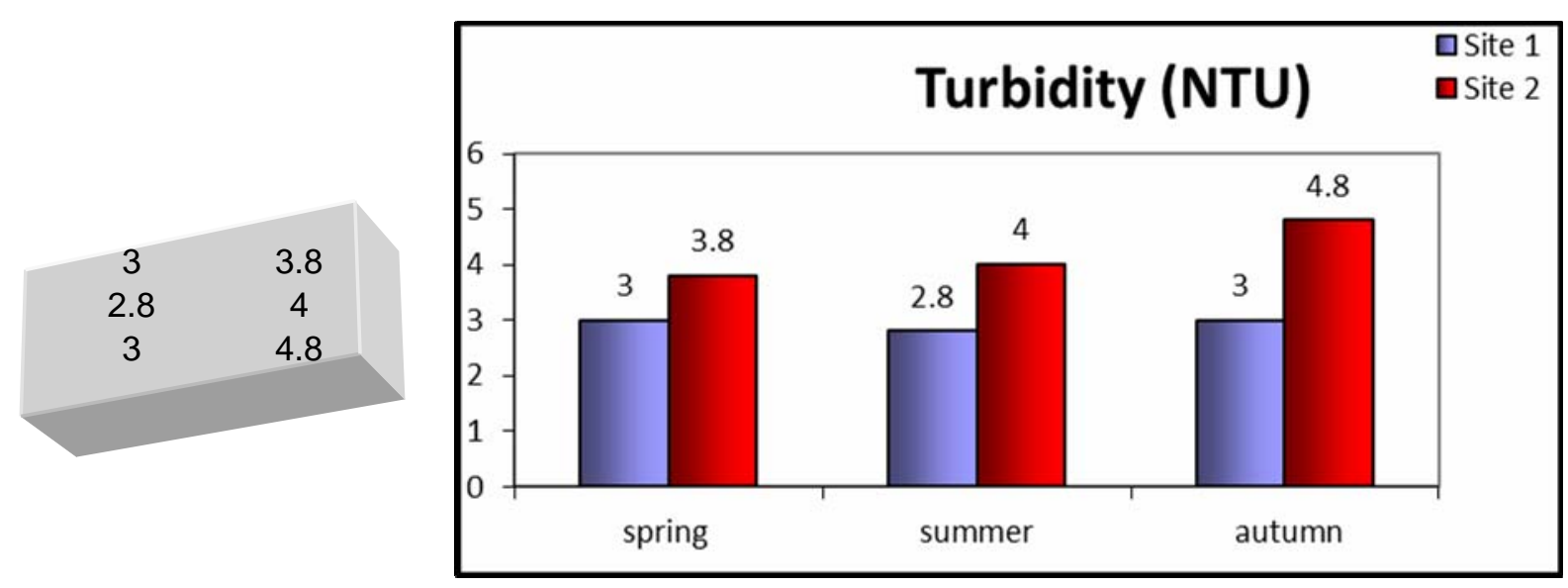

Fig. 3: Diagram of turbidity values during study period 


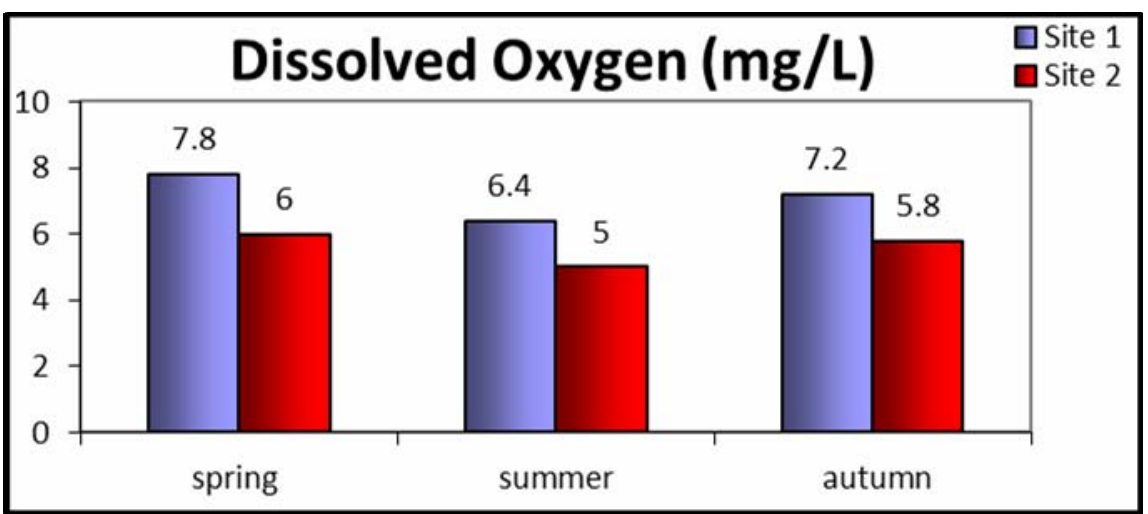

Fig. 4: Diagram of dissolved oxygen values during study period

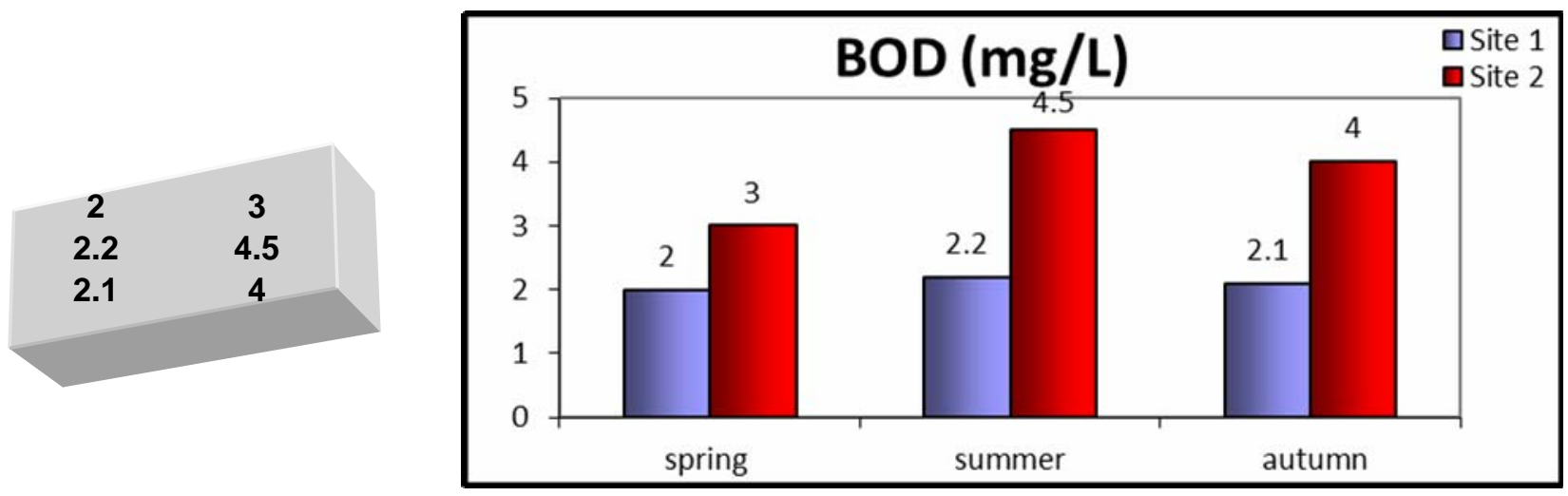

Fig. 5: Diagram of $\mathrm{BOD}_{5}$ values during study period

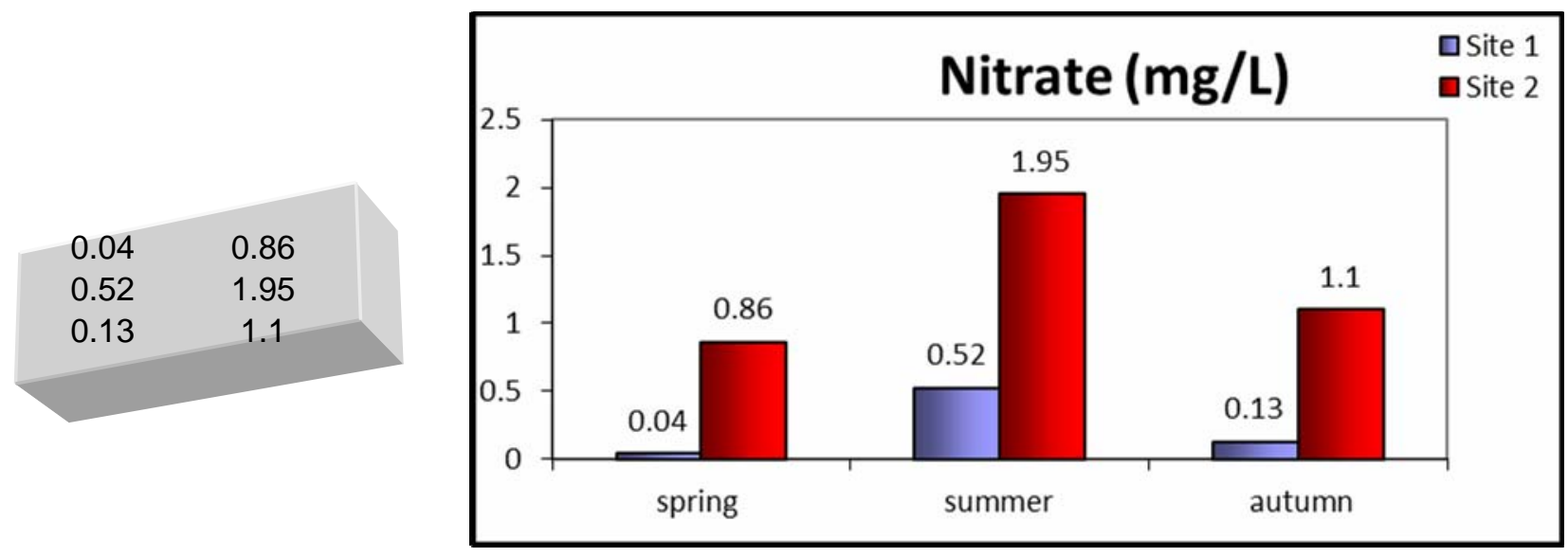

Fig. 6: Diagram of nitrate values during study period 

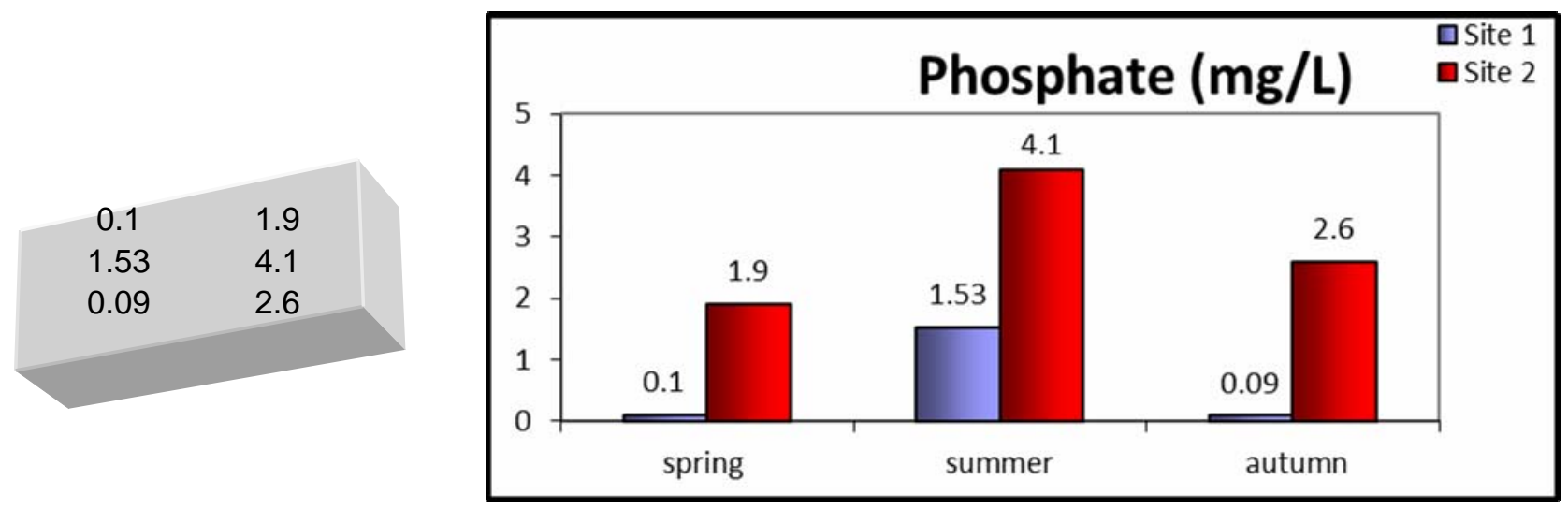

Fig. 7: Diagram of phosphate values during study period

Six species of hydrophytes and five species of Macro algae were identified as shown in table (2) and listed below:

Hydrophytes as shown in plates 1-6 included: Potamogeton pusillus, Potamogeton nodosus, Ceratophyllum demersus, Phragmites australis, Phragmites sp. and Typha sp., where macro-algae as shown in Plates 7-11 included: Hydrodiction riticulatum, Cladophora glomerata, Chara vulgaris , Chara sp. and Nitella sp., two species of hydrophytes and two species of macro-algae were found to be the dominant species, these are Potamogeton nodosus, Potamogeton pusillus and Hydrodiction riticulatum, Cladophora glomerata respectively. The dominate of Potamogeton sp. is matched with what was found from other researchers such as Kaplan (2002) about Potamogeton phenotypic plasticity and extensive morphological variation, Hrivnák et al., (2009) in a study of the seasonal dynamics for macrophytes abundance in regulated streams, and the study of Al-Wattar (2009) on the ecological and taxonomical study of Potamogeton in Tigris river through Nineveh province.

Table 2: Identified Hydrophytes and Macro Algae.

\begin{tabular}{|c|c|}
\hline Hydrophytes & Macro Algae \\
\hline Potamogeton pusillus & Hydrodiction riticulatum \\
\hline Potamogeton nodosus & Cladophora glomerata \\
\hline Ceratophyllum demersus & Chara vulgaris \\
\hline Phragmites australis & Chara sp. \\
\hline Phragmites sp. & Nitella sp. \\
\hline Typha sp. & --------------- \\
\hline
\end{tabular}

Also, the following photos clarify the density of hydrophytes and macro algae within the study area. 
Photos of collected hydrophytes and algae a-Photos of Hydrophytes

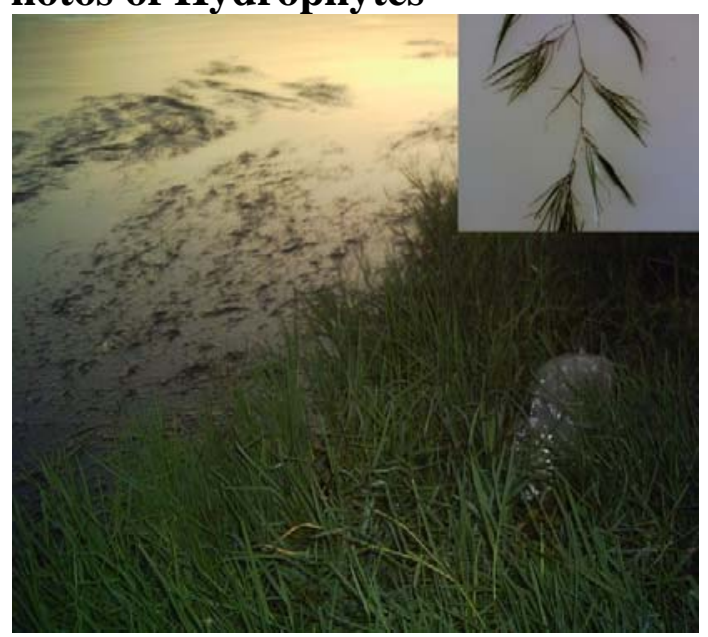

Plate 1: Potamogeton pusillus

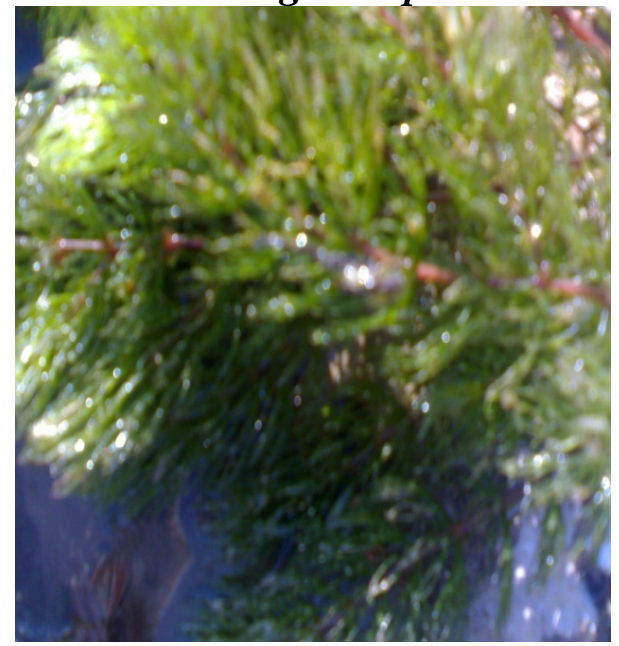

Plate 3: Ceratophyllum demersum

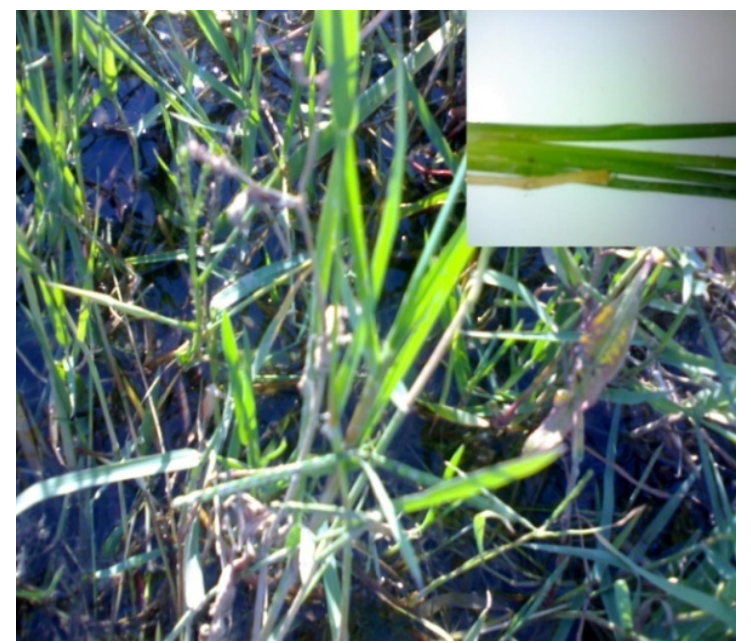

Plate 5: Phragmites sp.

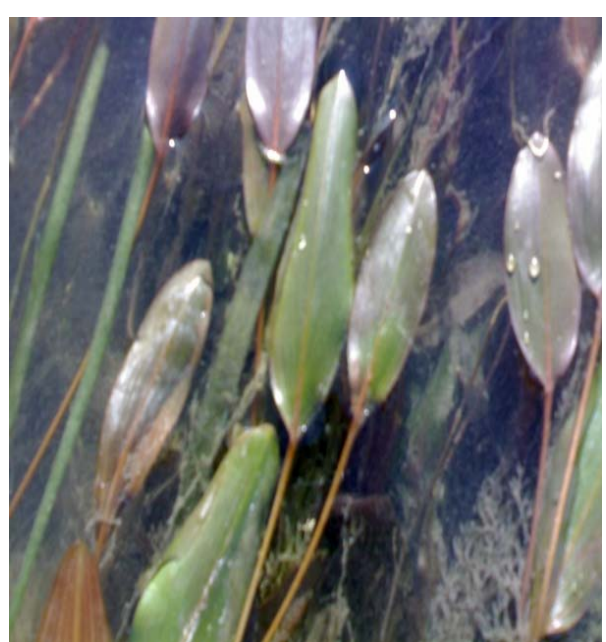

Plate 2: Potamogeton nodosus

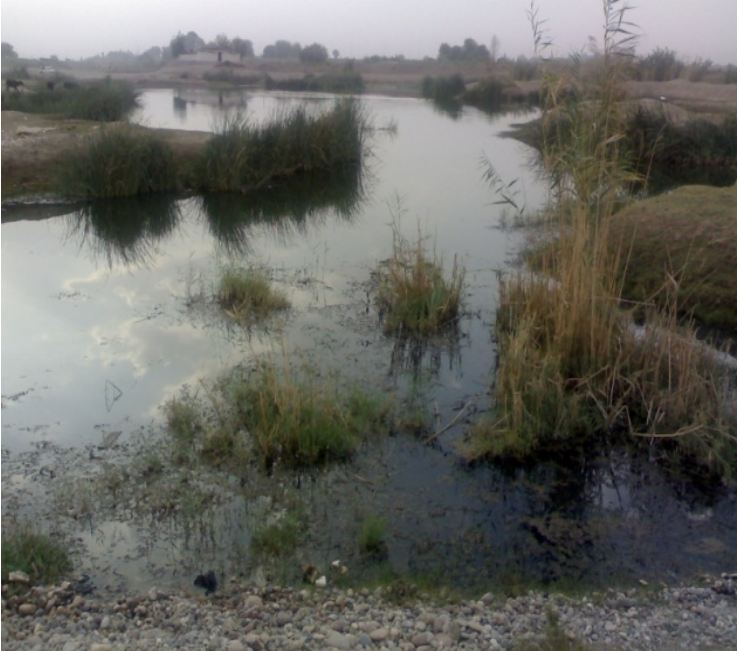

Plate 4: Phragmites australis

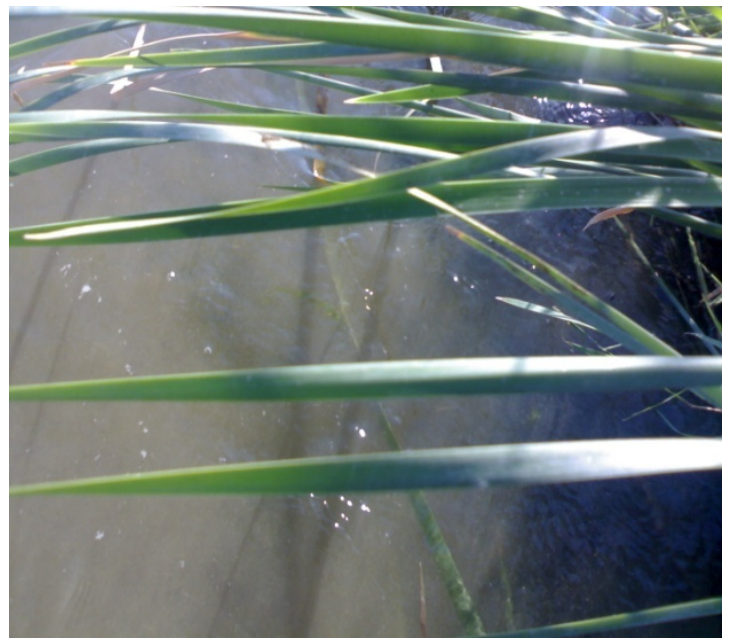

Plate 6: Typha sp. 


\section{b- Photos of Macro algae}

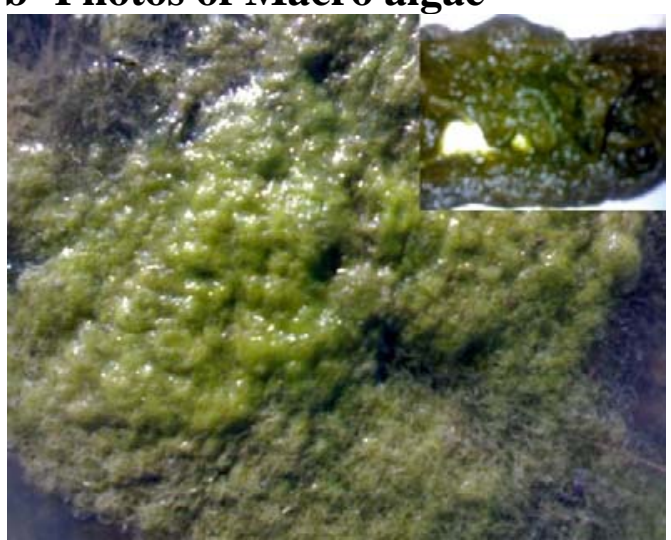

Plate 7: Hydrodiction riticulatum

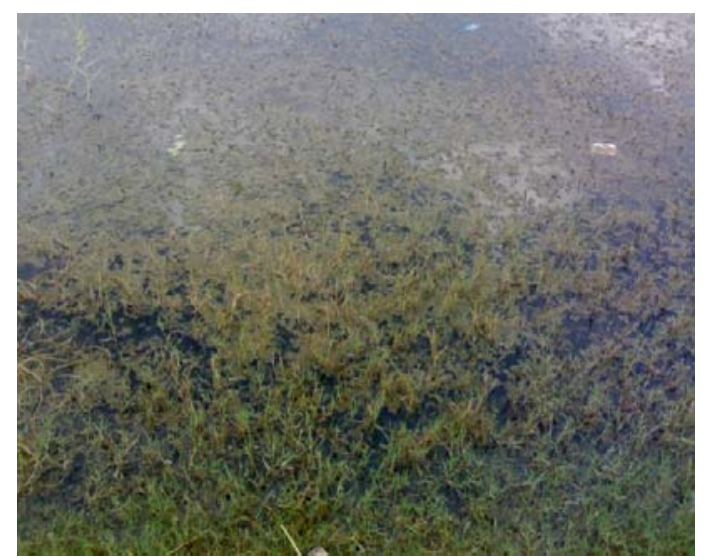

Plate 9: Chara vulgaris

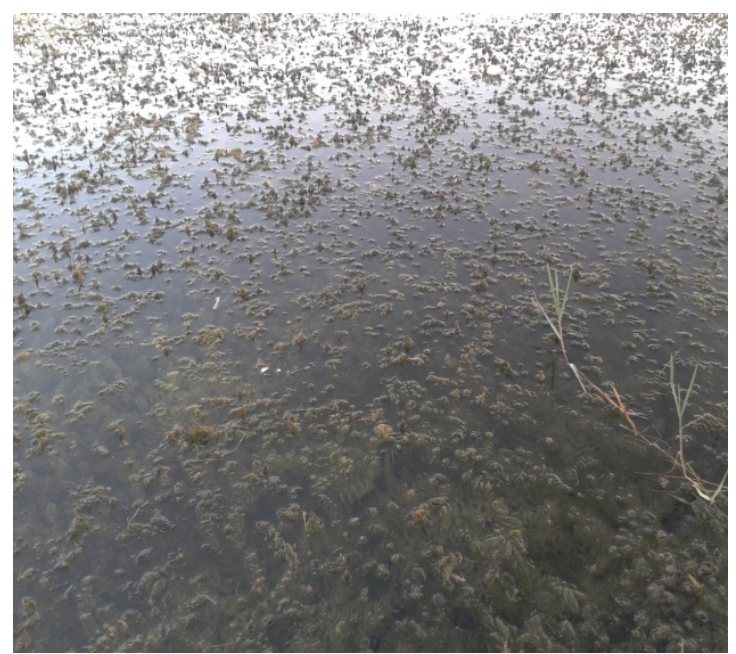

Plate 11: Chara sp.

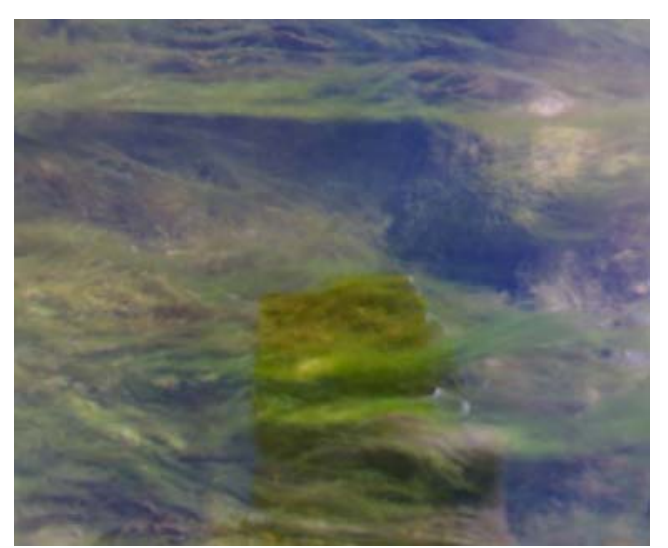

Plate 8: Cladophora glomerata

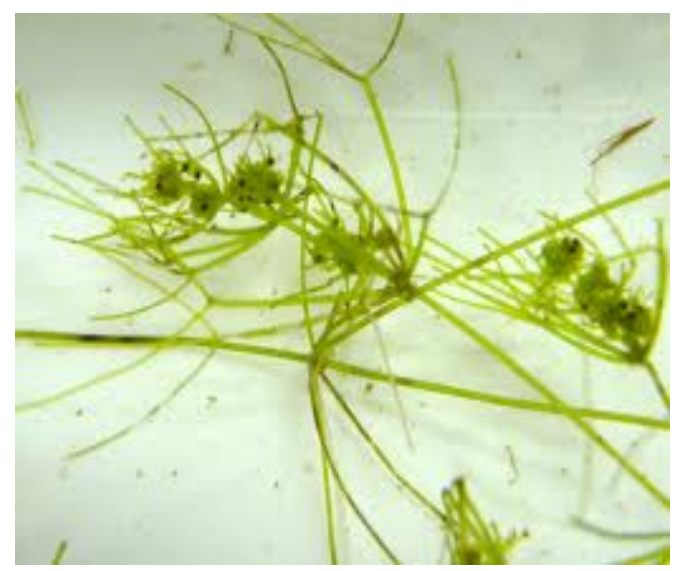

Plate 10: Nitella sp.

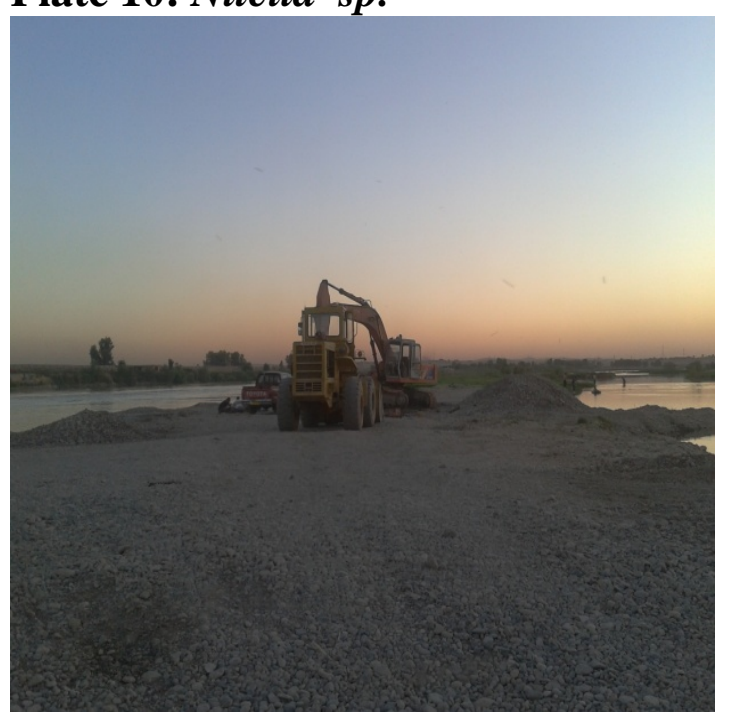

Plate 12: Sand and gravel along river path (Tigris river was cover this area) 


\section{DISCUSSION}

There is a great decrease in the river flow level in comparison with the previous years and the continuous decline so far (Al-Naqib et al., 2011), this decrease in the amount of water entering Iraq caused a change in the river flow model, and also in the river basin shape (Al-Ta`ee, 2008). There is a great and steady growth in the number of hydrophytes and algae developing in Tigris River. Researchers insure there is a negative impact of AlMosul Lake on the river ecosystem by diverting the flow of the river to the steady state (Al-Wattar, 2009). Sand and gravel queries scattered along the river banks with undesirable effects by urging aquatic plants and algae to grow vigorously.

The results showed serious problems regarding river water specifications within Iraqi territories. Water impoundment process inside and outside Iraqi territories affects negatively the quality and quantity of water, flow of the river inside the Iraqi territories does not exceed $350 \mathrm{~m}^{3} / \mathrm{sec}$ since entering the Iraqi territories, many studies confirm that water flow was much higher in the past years before dam construction (Al-Ni`ma, 1980; Talee, 1983; Al-Tayar, 1989).

Of other basic things that lead to the aggravation of the problem is the direct discharge of wastewater channels loaded with different elements which enhancing the growth of hydrophytes in the river, all of these effects are reflected fundamentally and clearly on the characteristics of the river, as follows:-

The process of water impoundment reflects on the temperature degree (Fig. 1) which in its turn directly affects the growth of aquatic plants and algae because the water came from the dark deep area of the lake. Therefore, dams cause general decrease in the temperature of water. Also, the turbidity (Fig. 3) factor which is considered one of the most important factors controls the photosynthesis in plants through affecting the light penetrating intensity within water column. The values of turbidity within Mosul city did not exceed (4.8) NTU through the period of study (Table 1), therefore, the light is available for the plants all over the year.

The local Iraqi water turn to alkalinity (Talling,1980), the fluctuation of $\mathbf{p H}$ (Fig. 2) values correlate with the dissolved $\mathrm{CO}_{2}$ which is balanced with the process of photosynthesis, whereas $\mathrm{CO}_{2}$ is considered the main output of the photosynthesis (AlSanjari, 2001), also $\mathrm{pH}$ values are affected by the wastewater discharge to the river directly without any treatment from (7) point sources through the study area (Mustafa and Fadhel, 2008).

Oxygen consumption (Fig. 4) in streams is affected by many of the variables as were described above: temperature, $\mathrm{pH}$, the presence of specific species of microorganisms, and the type of organic and inorganic material in the water.

Biological Oxygen Demand $\left(\mathbf{B O D}_{5}\right.$ ) directly affects the amount of dissolved oxygen in rivers and streams. Dissolved oxygen is consumed by micro-organisms through biodegradation of organic compounds; this means less oxygen is available to higher forms of aquatic life. The consequences of $\mathrm{BOD}_{5}$ (Fig. 5) raising are the same as those for dissolved oxygen drop: aquatic organisms become stressed, suffocate, and die (Delzer and McKenzie, 2003; APHA, 2005)

An acceptable aeration was recorded during this study, values of dissolved oxygen changed between upstream and downstream the river, oxygen levels affected by the parameters controlled the dissolution of oxygen gas in addition to the seasonal variation, 
abundance of dissolved oxygen correlated with the cold months, while a drop of oxygen was noticed in summer, it reached to $4.5 \mathrm{mg} / \mathrm{l}$ at downstream the river (Table 1 ), this may be due to the evaporation of the river during summer and because of the wastewater reached the river and AL-Khoser wastewater which contain an organic wastes consumed oxygen during the degradation by microorganisms (Fadhel et al, 2008). High values of dissolved oxygen recorded during spring season and that may return to the growth and reproduction of hydrophytes accompanied by oxygen releasing during photosynthesis (AL-Wattar, 2009). BOD 5 values indicate the organic load in water, the degradation of organic compounds by micro-organisms cause an increase in $\mathrm{BOD}_{5}$ values. Significant rising of $\mathrm{BOD}_{5}$ recorded in site 2 during summer season and that may relate to water temperature which affect the activity of micro-organisms in tissue degradation process and industrial/domestic organic load from wastewater channels(Sancom et al ., 2006).

Plant nutrients (P,N) concentration (Fig. 6 and 7) increase continuously with the discharge of wastewater and the age of the lake of Al-Mosul dam. Also, there is an agricultural activity along the river path effecting water quality by adding significant amounts of nutrients as a result of the processes of drifting and floods. Maximum levels of nitrogen and phosphorus recorded during summer season, with $\mathrm{P} / \mathrm{N}$ ratio ranged between (0.6:2.9) during the study period, the uptake kinetics of nitrogen $(\mathrm{N})$ and phosphorus $(\mathrm{P})$ by hydrophytes can be influenced by the interaction between $\mathrm{N}$ and $\mathrm{P}$, low $\mathrm{N}$ : $\mathrm{P}$ ratio indicates nitrogen limitation whereas, higher $\mathrm{N}$ : $\mathrm{P}$ ratios, potential phosphorus limitation (Wang et al., 2008). However, it has also been supported that these deviations from the typical N: P ratio values can also be linked to eutrophication problems, changes of the $\mathrm{N}$ : $\mathrm{P}$ atomic ratio was first related to excessive phosphorus loads from sewage (Karydis, 2009).

Nitrogen and phosphorus are of the main factors that caused this immense growth of aquatic plants and algae (Hrivnák et al., 2009; Hamdan et al., 2010) the concentration rate of phosphate in the river after the construction of the dam multiplied 150 times than been before construction, also the nitrate concentration that multiplies nearly 12 times than been before the construction of the dam (Scientific and Consultancy Services Office, College of Science, University of Mosul, 1988).

Controlling water movement by the construction of dams induces some kinds of water flow pattern instability leads to variation of water characteristics according to the flow pattern, in addition to what is being continuously discharged from the city sewer system (Mustafa and Fadhel, 2008).

Low level turbidity caused by reserving river water, the decline in water table besides changing the shape of river basin, all of that is necessary for hydrophytes and algal growth, which was obvious in this study.

The difference of hydrophytes species growing in the two sites (Table 2) could be due to water quality change through seasons and/or to the interspecies competition in specific environmental conditions (Spink et al., 1993), Potamogeton sp. (Sea Weeds) (Plate 1 and 2) was prevalent during the period of this study and in conformity with what was found by (AlWattar , 2009 ; Hamdan et al., 2010), while Chlorophyta phylum and sub-phylum Charophyta was most dominants divisions of Macro-algae and this presence is common in Iraqi fresh water.

Also water quality plays a role in shaping some plants species, the study of Arber (1972) shows the species Potamogeton perfoliates produced new leaves which were very thin when a typical plant put and grown in distilled water, this coincides by al Wattar (2009) 
which mentioned that morphological characters of leaves can't be accounted in order to differentiate between aquatic plants especially the related ones.

\section{CONCLUSIONS}

There is a clear impact of wastewater upon water quality and hydrophytes growth in Tigris river.

The existence of organic load and nutrients mainly nitrogen and phosphorous are very limiting factors for hydrophytes and algal growth and reproduction which is clearly found in the river.

Identified species in this study are common in fresh water community, also the decay of aquatic plants and algae causes’ odor, color, and a desirable test.

\section{RECOMMENDATIONS}

1. An agreement between riparian's must be signed regarding the amount of entering water.

2. Diminish water flow fluctuation to prevent environmental disturbance within the river course.

3. Excavation and trimming of banks may prevent the dispersion and growth of hydrophytes.

4. Minimizing untreated wastewater discharged to river basin.

\section{REFERENCES}

Al-Mayah, A.A. ; Al-Hamim, F.H. (1991). "The Aquatic Plants and Algae". 1st and 2nd volumes, Basrah University, Iraq, pp. 78-112.

Al-Naqib, S. Q. ; Mustafa, M. H. ; Shihab, A. S. (2010). The expected impact of the Turkish ilisu dam under construction upon Tigris river water quality. The 7th Period. Scie. Conference of Dams and Water Resources Research Center, 24-25 Nov., 33-47.

Al-Ni ma, B. (1980). A study on the Limnology of Tigris and Euphrates Rivers. Msc thesis, University of Salahuddin, College of Science, Erbil, Iraq.

Al-Sanjari, M. N. (2001). Ecological Study of Tigris River within Mosul City. Msc thesis, University of Mosul, College of Science, Mosul, Iraq. (in Arabic)

Al-Ta`ee, T. M. (2008). Statistical prediction of Tigris river levels at Mosul hydrological station, north Iraq. The 6th Period. Sci. Conference of Dams and Water Resources Research Center, 27-28 Oct., 15-33.

Al-Tayar, T. A. (1989). Dam Impact upon Water Quality and Its Effect on the Efficiency of Water Treatment Plants in Mosul City. MSc thesis, University of Mosul, College of Engineering, Mosul , Iraq.(in Arabic)

Al-Wattar, M.T. (2009). Ecological and Taxonomical Study of Potamogeton L. in Tigris River Passing Through Nineveh Province. Ph. D. Thesis, University of Mosul, College of Science, Mosul, Iraq.(in Arabic)

APHA, American Public Health Association (2005). 'Standard Methods for the Examination of Water and Wastewater" 21st ed., APHA AWWA WEF, United States of America, pp. 41-192. 
Arber, A (1972). 'Water Plants , A study of Aquatic Angiosperms." Cambridge University press, United Kingdom, pp. 46-65.

Delzer, G.C.; McKenzie, S.W. (2003). "Five-Day Biochemical Oxygen Demand." 3rd ed., USGS TWRI Book, United States of America, pp. 4-18

Fadhel, M. N.; Khattab, M. F.; Nuaimy, H. J. (2008). Adverse impact of Al-Khoser river upon Tigris river at outfall area. Iraqi. J. for Earth Sci., 8 (1), 41-54.

Fassett, N.C. (1975). "A Manual of Aquatic Plants". 1st ed., the University of Wisconsin Press, United States of America, pp. 12-23.

Ghazal, I.K. (1996). Some physical and chemical differences between upstream and downstream in Tigris river within Mosul city. Tikrit J. Pure Sci., 5 (4), 34-349.

Hamdan, M. A.; Hassan, F. M.; Asada, T.; Warner, B. G.; Douabul, A.; Asada, T.; Warner, B. G.; Douabul, A.; Al-Hilli, M. R.; Al- Alwan, A. A. (2010). 'Vegetation Response to Re-flooding in the Mesopotamian Wetlands, Southern Iraq", Society of Wetland Scientists, Springer DOI 10.1007/s13157, pp. 1-8.

Hrivnák R.; Helena O.; Dušan G. (2009). Seasonal dynamics of macrophyte abundance in two regulated streams. Cent. Eur. J. Biol., 4 (2), 241-249.

Kadah, N. (2001). The safe management for water resources. AL- Kafilla Cultural J., 50, 33-39.

Kaplan, Z. (2002). Phenotypic plasticity in Potamogeton (Potamogetonaceae). Folia Geobotanica J., 37, 141-170.

Karydis, M. (2009). Eutrophication assessment of coastal waters based on indicators: a Literature review. Global NEST J., 11 (4), 373-390.

Muencher, W.C. (1959). "In Edmondson (Ed.) Fresh Water Biology (Vascular plants)"John Wiley and sons, New York, pp.14-26.

Mustafa and Fadhel (2008). The eutrophication of Tigris river within Mosul area. The 6th Period. Sci. Conference of Dams and Water Resources Research Center, 27-28 Oct., 1-14.

Prescott, G. W. (1978). "How to Know Freshwater Algae". 3rd ed., WCB McGraw-hill company, United States of America, pp.24-33.

Sancom, A.; Sopajaree, K.; Cheunbarn, T. (2006). Effect of temperature on total organic carbon degradation using Trichderma fungi in co-composting of straw and hospital sewage sludge. 2nd joint International Conference on Sustainable Energy and Environment (SSE 2006), 21-23 Nov., Bangkok, Thailand.

Scientific and Consultancy Services Office, (1988). Study the reasons for worsening growth of algae and other plants in Tigris river. Report presented to the College of Science, University of Mosul, Iraq, pp. 2-8.

Spink, A. J.; Murphy, K. J.; Smith, S.M.; Westlake, D.F. (1993). Effects of eutrophication on Rununculus and Potamogeton. J. Aquat. Plant Manage., 31, 113-117.

Talee, A. Y. (1983). 'Study the Seasonal Effects of the Proposed Wastewater from the City of Mosul on the Tigris River Water Quality and their Suitability for Irrigation, 
Drinking and Industry". Msc Thesis, University of Mosul, College of Agriculture, Mosul, Iraq. ( in Arabic).

Talling, J. F. (1980). Euphrates and Tigris mesopotamia ecology and density by Julian Rzoska. Monographiae Biologicae J., 38, 63-80.

Townsend, C.C.; Guest, E. (1985). Flora of Iraq. Vol. 9, Government Publication, Ministry of Agriculture, Baghdad, Iraq.

Wang, C.; Yan, X.; Wang, P.; Chen, C. (2008). Interactive influence of N and P on their uptake by four different hydrophytes. African J. Biotechnology, 7 (19), 3480-3486.

WHO, World Health Organization (1998). 'Guidelines of Drinking Water Quality". 3rd ed., Geneva, Switzerland, pp. 6-32. 